\title{
RELIGION, CONSTITUTION, AND HUMAN RIGHTS: AN OVERVIEW OF MUSLIM LIFE AND RELIGIOUS FREEDOM IN THE UNITED STATES
}

\author{
Suci Ramadhan ${ }^{1 *}$ \\ ${ }^{1}$ Syarif Hidayatullah State Islamic University Jakarta, Indonesia, e-mail: suciramadhan95@gmail.com \\ *Corresponding author \\ (c) (1) (2) \\ (C)2021 by the authors. Submitted for possible open access publication under the terms and conditions of the Creative Commons \\ Attribution-ShareAlike 4.0 International License-(CC-BY-SA) (https://creativecommons.org/licenses/by-sa/4.0/) \\ doi DOI : http://dx.doi.org/10.30983/islam realitas.v7i2.4801

Submission: 21 September $2021 \quad$ Revised: 14 December $2021 \quad$ Published: 31 December 2021

\begin{abstract}
This research aims to analyze the intersection of religion, constitution, and Muslim human rights in the United States. The United States Constitution affirms that religious freedom is a fundamental human right regardless of religion. It is upheld by every citizen and the country. However, the political policies in the United States are often considered to paralyze fundamental rights in religion, causing various problems in the life of Muslims living in the country. This study uses qualitative research method with the lens of political approach. Data are taken from the United States Constitution and policies, various books, scientific articles, and news. Data are collected by documentation technique and analyzed with political discourse analysis. The results suggest that anti-Muslim sentiment is found in the political policies of the United States. Currently, the unconstitutional and discriminative policies are gradually removed because it triggers social and political chaos. The United States constitution strives towards a pluralist and multi-religious country rebuilding that is safe and peaceful for any religion as guaranteed by the constitution.
\end{abstract}

Keywords: Constitution, Human rights, Muslim life, Religious freedom.

\begin{abstract}
Abstrak
Penelitian ini bertujuan untuk menganalisis persinggungan agama, konstitusi dan bak asasi muslim di Amerika Serikat. Konstitusi Amerika Serikat menegaskan bahwa setiap warganegara berbak. untuk. memiliki kebebasan beragama, tanpa melihat latar belakang agama tertentu. Kebebasan beragama tersebut harus dijunjung tinggi oleh siapa dan apapun, termasuk negara. Hanya saja, dinamika politik kebijakan yang dikeluarkan Amerika Serikat seringkali dinilai melumpubkan hak-hak dasar dalam beragama sebingga menimbulkan problematika pada kebidupan muslim. Studi ini menggunakan metode penelitian kualitatif dengan pendekatan politik. Data bersumber dari Konstitusi dan kebijakan Amerika Serikat, berbagai buku, artikel ilmiah dan berita. Pengumpulan data menggunakan teknik. dokumentasi, kemudian dianalisis menggunakan analisis wacana politik. Hasil penelitian ini menunjukean bahwa sentimen anti Islam ditemukan dalam kebijakan-kebijakan politik pemerintah Amerika Serikat. Saat ini, kebijakan yang dinilai inkonstitusional dan diskriminatif tersebut secara perlahan mulai dibapuskan karena telab menimbulkan kekeacauan sosial dan politik. Sejalan dengan itu, Amerika Serikat terus berupaya membangun kembali negara pluralis dan multireligius yang aman dan damai bagi para pemeluk agama sebagaimana yang telah dijamin oleh konstitusi.
\end{abstract}

Kata Kunci: Konstitusi, Hak ssasi manusia, Kehidupan Muslim, Kebebasan beragama.

\section{Background}

The United Nations was established in 1946 with the aim to formulate and define provisions concerning human rights for all people from various cultural, religious, racial, and ethnic backgrounds. ${ }^{1}$ In the Universal Declaration of Human Rights which was proclaimed in 1948 and International Covenant 1966, those rights have now become international law. They even grow to

1 Rhoda Asikia Ige Nee Karibi, 'Religion, Human Rights and the Challenges of Freedom', Peuradeun, 3.1 (2015), 42. 
be political response to the emergence of the modern state. ${ }^{2}$

The Universal Declaration of Human Rights is considered to be the starting point in providing a better life for all people around the world, the United States (henceforth, the US) is no exception as one of the countries that intensively upholds human rights. ${ }^{3}$ Despite not ratifying most of the policies, it is one of the countries that oversees the establishment of human rights policies during the 20th century. This sort of paradox is seen in the number of US policies that are in contrast to the values and principles of human rights, especially pertaining to issues of religion (specifically Islam).

Widespread human rights policies cause tensions in understanding religious teachings, and social, economic, and political realities among Muslims around the world, including the US. They lead to an unfavorable situation for Muslims' faith realization. ${ }^{4}$ Islam has become a highly controversial and misunderstood religion in the US. Some incidents of terrorism, such as the $9 / 11$ tragedy, are often related to Islam. These increase sentiments towards Islam create negative pressure from various parties. ${ }^{5}$

Muslim life in the US has experienced the ups and downs of political configurations in recent decades. Some policies issued by the constitutions tend to interfere with Muslim freedom in the US,

${ }^{2}$ Ahmad Nur Fuad and others, 'Islam and Human Rights in Indonesia: An Account of Muslim Intellectuals' Views', Al-Jami' ab: Journal of Islamic Studies, 45.2 (2007), 24187 <https://doi.org/10.14421/ajis.2007.452.241-287>.

3Zuman Malaka, 'Ham dan Demokrasi dalam Dunia Islam', Al-Qanun, $12.2 \quad$ (2009), 359-360 <https://doi.org/https://doi.org/10.15642/alqanun.2009 12.2.359-384.

4 Sus Eko Ernada, 'Issues of Compatibility of Human Rights and Islam: The Experience of Egypt and Indonesia', Journal of Indonesian Islam, 1.1 (2007), 100-134 <https://doi.org/10.15642/JIIS.2007.1.1.100-134>.

${ }^{5}$ Kazi I. Hossain, 'Understanding Islam in the U.S. Classroom: A Guide for Elementary School Teachers', Multicultural Education, 20.2 (2013), 52.

${ }^{6}$ Jana Milia and Yusnarida Eka Nizmi, "Kebijakan Luar Negeri Amerika Serikat Terhadap Kelompok Terorisme Al-Qaeda Pada Masa Pemerintahan Barack Obama," JOM FISIP, 2.2 (2015).

7 Aziddin Harahap, "Realitas Kontemporer Islam dan Keragaman Amerika Serikat dan Kanada," Jurnal even though the constitution has guaranteed protection and equal life for all religions. Unconstitutional policies violate human rights values regarding religious freedom and inflict chaos at the national and international levels.

Several studies on religious freedom concerning religion and country have been conducted by many researchers, such as Adi Joko, Aziddin, Ismatu Ropi, Andika, Jessica Tiolina, Jawahir Thontowi, Abu Bakar Jana Milia and Nizmi, and Indriana. My study provides new insights by examining relevant previous studies. Jana Milia and Nizmi ${ }^{6}$ and Aziddin ${ }^{7}$ have revealed that George W. Bush's policies on counter terrorism triggered by the $9 / 11$ tragedy have given Islam a terrorist face. However, Jessica Tiolina explained that the policies have changed in the Obama era, in which diplomatic efforts were made to Muslim countries without prejudice to the counterterrorism effort. ${ }^{8}$

During Trump's presidency, Muslims face another dilemma. According to Adi Joko9, Trump asserted that the increasing number of migrations from Muslim-majority countries to The US caused the threat of terrorism to the country. Andika ${ }^{10}$ strengthened the above statement. He revealed that Muslim countries allied to terrorism are considered to have threatened the stability of the US and cause the Muslim ban policies. However, Jawahir Thontowi ${ }^{11}$ explained that Muslim ban's

Ekonomi Bisnis Manajemen dan Akuntansi, 1.1 (2020), 69-80 <https://doi.org/10.36987/ebma.v1i1.1901>

8 Jessica Tiolina, "Analisis Serangan Drone dalam Aksi Counter Terrorism Terhadap Hubungan Amerika Serikat dan Pakistan Pada Masa Pemerintahan Presiden Barack Obama," Journal of International Relations, 4.4 (2018), 858-67 <http://ejournal-s1.undip.ac.id/index.php/jihi>

9 Adi Purwanto Joko, "Sekuritisasi Terhadap Imigran Negara Mayoritas Muslim di Amerika Serikat Era Presiden Donald Trump," Spektrum, 18.1 (2021).

10 Adhika Isthianto Utomo, "Kepentingan Amerika Serikat dan Prancis dalam Intervensi Kemanusiaan di Libya Pada Tahun 2011," Journal of International Relations, 4.4 (2018), 822-831 <https://ejournal3.undip.ac.id/index.php/jihi/article/vie $\mathrm{w} / 22004>$.

11 Jawahir Thontowi, "Kebijakan Presiden Trump dan Respon Masyarakatnya Terhadap Larangan Muslim Arab Tinggal di Amerika Serikat," Jurnal Hukum IUS QULA IUSTUM, 24.3 (2017), 369-92 <https://doi.org/10.20885/iustum.vol24.iss3.art2>. 
policies had violated international law and human rights.

On the other hand, Indrian ${ }^{12}$ stated that discriminatory US policies against Muslims are due to a lack of understanding of Islam. The stereotype that Islam is a terrorist religion is still difficult to dispel in the US. In fact, according to Abu Bakar ${ }^{13}$, Islam is the religion that always upholds tolerance for every religion, whenever and wherever it exists. In addition, Ismatu Ropi ${ }^{14}$ argued that religion and the state must work in a parallel and accommodating framework. This means that religious adherents are not only free to practice their religious values but also must follow the state policies for the creation of a safe and peaceful country.

Based on the previous relevant works of literature, the writer finds that those studies generally discussed the political dynamics of the US government. There is no study on religious freedom that focuses on constitutional and human rights issues. Thus, this study aims to analyze the intersection of religion, constitution, and Muslim human rights in the United States.

This is qualitative research with a political approach. ${ }^{15}$ The research data are secondary data taken from the US constitution and political policies, various books, scientific articles, public documents, and also news about the US, Islam and Muslim life in the US. Data are collected by documentation technique through searching and finding literatures related to research data. Then, data is analyzed with political discourse analysis. Political discourse analysis is critical analysis in interpreting texts on the reproduction and

12 Indriana Kartini, "Dinamika Minoritas Muslim di Amerika Serikat," Jurnal Penelitian Politik, 2.1 (2005), 97-107 <https://doi.org/10.14203/jpp.v2i1.405>.

13 Abu Bakar, "Konsep Toleransi dan Kebebasan Beragama," Toleransi: Media Komunikasi Umat Beragama, 7.2 (2015), 123-131.

${ }^{14}$ Ismatu Ropi, "Konstitusi dan Nomenklatur Kebebasan Beragama: Pengalaman Berbagai Negara," Jurnal Ilmu Ushuluddin, 7.1 (2020), 57-82 <https://doi.org/10.15408/iu.v7i1.14411>.

15 The political approach in this research examines the constitutional system that emphasizes its political functions, including policy considerations of the political elite and public participation in policy-making country. See, contestation of political power. According to Fairclough, this analysis can contribute to answering the political problems that occur, by limiting the subject of the analysis related to the formal or informal political context attached to political actors consisting of politicians, citizens, political institutions, government, political media, and political supporters. ${ }^{16}$

\section{Muslim Growth and the Demographics Portrait in the United States}

The US census statistics agency surveyed in 2017 to estimate Muslim population in its country. It resulted that there are approximately 3.45 million Muslims in the US or about $1.1 \%$ of the total US population. In 2015, Pew Research carried out a project that Muslims in the United States could reach 3.85 million by 2020 .

Chart 1. Muslim Growth in the US

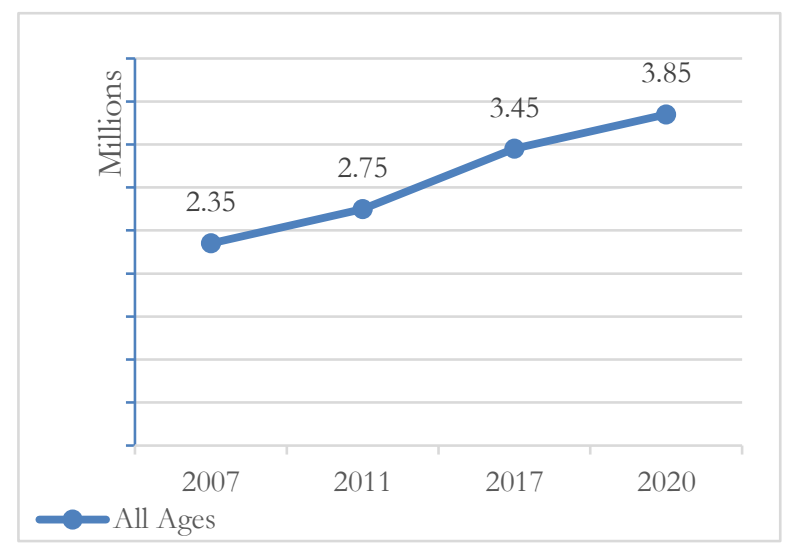

Source: PEW Research Center ${ }^{17}$

The Council on American-Islamic Relations (henceforth, the CAIR) disagreed with Pew Research's 2011 survey of the US Muslim population of about 2.75 million people. The

Paul Pennings, Hans Keman, and Jan Kleinnijenhuis, Doing Research in Political Science (London: Sage Publications, 2006)., p. 26

16 Norman Fairclough and Isabela Fairclough, Political Discourse Analysis: A Method for Advanced Students. (United Kingdom: Routledge, 2012)., p. 17-18

17 Besheer Mohamed, "Muslims Are a Growing Presence in U.S., but Still Face Negative Views from the Public," Pew Research Center (the United States of America, 2021) < <ttps://www.pewresearch.org/fact$\operatorname{tank} / 2021 / 09 / 01 /$ muslims-are-a-growing-presence-in-u-sbut-still-face-negative-views-from-the-public/ $>$ [accessed 18 December 2021] 
CAIR made several major findings in 2011 regarding the growth of Muslims in the US as measured by the growth in the number of mosques. With the number of mosques and total Muslim population in the US, it should be around 7 million people. ${ }^{18}$ The latest research made by Institute for Social Policy and Understanding (ISPU) in 2020 found that the number of mosque worshipers, as measured by the number of Muslims attending Eid prayers, increased to 1445. This indicates an increase of 16\% from 2010's total of 1248 . Using the calculation of the number of worshipers for Eid prayers, which are around 4 million, it is estimated that the Muslim population in 2020 should reach more than 7 million people. ${ }^{19}$

Based on the demographic research projections, Muslims will continue to make up $2.1 \%$ of the US population by 2050 , surpassing Judaism as the country's second-largest religious group (excluding those who profess to be atheists). ${ }^{20}$ If the current trends continue, then the Muslim population in the US will become larger in the next 2 decades, from 2.6 million in 2010 to 6.2 million in 2030. This means that the demographic projection increases by 5.6 million and the most Muslim immigrants coming to the US and Canada are from South Asia, the Middle East, and North Africa. $^{21}$

At the present time, about $58 \%$ of adults from the first generation of Muslims are those who immigrated to the US, while about $42 \%$ are Muslims born the US. As for the region, the majority of Muslim population reside in the California area with a $1,000,000$ population; New
York: 800,000; Illinois: 420,000; Michigan: 170,000; Indiana: 180,000; Virginia: 150,000; Texas: 140,000; and Ohio: 130,000. This number represents 3.3 million or $45 \%$ of the total Muslim population in the US. ${ }^{22}$

The US is one of the countries that responds well to the issue of Muslim demographics. Some Muslim immigrants argue that religious respect in the US is more secular than in European countries and causes the Muslim growth to increase year by year compared to other western countries. ${ }^{23}$ The implementation of secularism between Europe and the US cannot be separated from the historical background of the secularism emergence in both countries. Like France, which implements the separation of religion and state due to conflicts between the Catholic Church and Republican groups. This led to the notion of separating religion from the state by emphasizing all citizens to assimilate under a unified community of citizens, without any differences as known as The French Laïcité ${ }^{24}$ This secularism model has an impact on the prohibition of any religious symbols to be used in the public sphere, to maintain their secularist characteristics.

In the US, the separation that occurs between religion and state aims to protect religious freedom and avoid inter-religious conflicts in the country. The impact is that the state is not allowed to privilege or provide special facilities for certain religions, and religion is also not a tool of social integration. Therefore, a person who embraces a religion in the US is free to express himself in the

Muslim Minority Affairs, 22.2 (2002), 369-80 <https://doi.org/10.1080/1360200022000027320>, p. 371.

23 Amin Asfari and Anas Askar, 'Understanding Muslim Assimilation in America: An Exploratory Assessment of First \& Second-Generation Muslims Using Segmented Assimilation Theory', Journal of Muslim Minority Affairs, $\quad 40.2 \quad$ (2020), <https://doi.org/10.1080/13602004.2020.1781467>, p. 2. ${ }^{24}$ Sylvie Bacquet, "Religious Freedom in a Secular Society: An Analysis of the French Approach to Manifestation of Beliefs in the Public Sphere," SSRN Electronic Journal, 9.October (2012), 1-15 <https://doi.org/10.2139/ssrn.1753229>. 
public sphere and show the religious symbols he believes in. ${ }^{25}$

\section{Human Rights and Religious Freedom Protection in The United States Constitution}

Human rights are fundamental values and legal guarantees and protections inherent in every human being regardless of social background, culture, race, ethnicity, religion, language, gender, nation, and state. These include respect, fulfillment, and protection for free-living without any suppression and slavery, the rights to opinion and expression, to work, and to receive education. ${ }^{26}$ Human rights are also considered as a set of norms governing the treatment of individuals and groups by the state or non-state actors based on ethical principles on what is considered fundamental by society for a decent life. ${ }^{27}$

Human rights implementation in the form of an anti-discrimination policy includes constitutional protection of civil rights, legal processes, and equal protection. In addition, the policy also serves to protect immigrant groups and facilitate their integration into society. It can be summed up that anti-discrimination policies empower immigrant groups by minimizing their experience of differential treatment, harassment, threatening, or harmful behavior based on personal characteristics, such as religion, race, immigration status, and national origin. ${ }^{28}$

The implementation of human rights policies was originally stated in the United States Declaration of Independence in 1776 which reads: "...that all men are created equal, that they are endowed by their creator by certain unalienable rights, that among these are life, liberty, and pursuit of happiness..."29 In January 1941, under Franklin D. Roosevelt's presidency, a vision was announced for a post-war world system called the Four Freedoms which aims to ensure human safety and security. They are freedom of speech, freedom of worship, freedom from want, freedom from fear. Over the next several years, the Four Freedoms became an inseparable part of modern international law. The 1945 United Nations Charter sets this vision as a basic principle in the 1948 Universal Declaration of Human Rights. ${ }^{30}$ On December 10th, 1948, the United Nations Assembly issued a pronouncement called the Universal Declaration of Human Rights by 48 countries voted in favor, eight countries abstained, and not a single country refused. ${ }^{31}$

International law guarantees the fundamental rights of every human being in every part of the world. However, the standard policies regarding human rights cannot be applied generally in the US. Thus, the country formulates its legal policies to be implemented in each region and federal territory. This phenomenon has made the US more aggressive in implementing human rights principles in the country's various political policies, which sometimes conflict with constitutional principles and human rights values, particularly those related to religious life. ${ }^{32}$

From the very beginning, the US constitution has advocated for human rights. In
${ }^{25}$ Mohammad Takdir, "Contestation and the Roles of Islam in The Public Sphere: A Sociological Analysis of Religious Secularization in Indonesia and the West," Afkaruna: Indonesian Interdisciplinary Journal of Islamic Studies, 20.2 (2020), 163

<https://doi.org/10.18196/aiijis.2020.0119.154-174>.

26 Human Rights, Terrorism and Counter-Terrorism (Switzerland, 2008)., p. 3

${ }^{27}$ Stephen P Marks, Human Rights: A Brief Introduction, Harvard School of Public Health, 2014, p. 1.

${ }^{28}$ Saltanat Liebert, Mona H. Siddiqui, and Carolin Goerzig, 'Integration of Muslim Immigrants in Europe and North America: A Transatlantic Comparison', Journal of Muslim Minority Affairs, 40.2 (2020), 196-216 <https://doi.org/10.1080/13602004.2020.1777663>.
29 Declaration of Independence (the United States of America, 1776)., p. 1

${ }^{30}$ R. Shulman Mark, "The Four Freedoms: Good Neighbors Make Good Law and Good Policy in a Time of Insecurity," Fordham Law Review 77, no. 2 (2008): 555-581, https://ssrn.com/abstract $=1287160$.

31 Ahmad Muhtarom, 'Diskursus Islam Dan Hak Asasi Manusia (Kajian Universalitas Dan Kasus Pelanggaran Hak Asasi Manusia)', FIKRI: Jurnal Kajian Agama, Sosial Dan Budaya, 2.1 (2017), 113 $<$ https://doi.org/10.25217/jf.v2i1.83>.

32 Oktoviana Banda Saputri, 'Diskriminasi Ras Dan Hak Asasi Manusia Di Amerika Serikat: Studi Kasus Pembunuhan George Floyd', Jurnal Sosiologi Pendidikan Humanis, $\quad 5.2 \quad$ (2020), 120 <https://doi.org/10.17977/um021v5i2p120-133>. 
1791, the US made the first 10 amendments known as the Bill of Rights. These amendments outline broad principles based on ideas that have been accepted by some countries as the fundamental principles of the constitutional structure. $^{33}$ The first amendment contains the aspect of religion, speech, and freedom of the press:

Amendment 1 - Freedom of Religion, Press, Expression

"Congress shall make no law respecting an establishment of religion, or prohibiting the free exercise thereof; or abridging the freedom of speech, or of the press; or the right of the people peaceably to assemble, and to petition the Government for a redress of grievances." ${ }^{\text {"34 }}$

The first amendment states that Congress will not enact laws that promotes a certain religion, prohibit religious practice, or restrict freedom of speech, or freedom of the press, or the rights of the community to assemble peacefully, and petition to the government to respond to a complaint.

The first amendment contains two clauses that regulate the relationship between government and religion. The main clause states that "Congress will not pass laws respecting religious establishments", or in other words, the main clause prohibits the adoption of an official religion by the federal government. It can be understood that the clause ensures the federal government will not support or oppose any religion. However, the Supreme Court has tolerated government involvement in religion, such as supplying government funds to private religious schools and reciting a prayer to start certain legislative meetings as happened in Town of Greece V. Galloway. ${ }^{35}$

The second clause of the first amendment states: "Congress shall not enact laws that respect religious establishments, or prohibit the practice." In line with the first clause which prohibits Congress from adopting certain religions, the second clause prohibits Congress from interfering in one's religious practice. The clause protects individuals from laws that would prevent them from engaging in religious practices so that they can believe and doing their religious rituals. ${ }^{36}$ The provisions in the Bill of Rights explicitly limit the federal government, not the states. However, Referring to the 14th Amendment, the Supreme Court held that the protection of religious freedom in the First Amendment could apply to both states and local governments.

\section{Anti-Muslim Policies in the Political Configuration of the United States}

After the 9/11 attack on the World Trade Centre, the US government reviewed immigration policies and national security measures. The US Patriot $\mathrm{Act}^{37}$ was enacted following the tragedy and signed into law. It authorizes the attorney general to detain non-citizens suspected of terrorism without a warrant and passes new surveillance guidelines for US law enforcement agencies. The 9/11 attack has heightened public fear and raised the idea that Muslims are not part of the West. For instance, since 2010 the US introduced 201 laws known as "anti-sharia" laws in 43 states aimed at preventing the influence of Islam in the country. ${ }^{38}$ In fact, according to the state constitution in the 14th amendment regarding citizenship rights, it is stated that states may not make laws that limit the rights of citizens.
33 Ian Loveland, Constitutional Law, Administrative Law, and Human Rights: A Critical Introduction, 6th Editio (Great Britain: Oxford University Press, 2012), p. 559.

34 Amendment 1-Freedom of Religion, Press, Expression,"The Constitution of the United States", ratified in December 15, 1791.

Institute

35"Religion and Constitution," Legal Information

$<$ https://www.law.cornell.edu/wex/religion_and_the_co nstitution $>$ [accessed 19 April 2021].
36 "Religion and Constitution."

37 The Clear Law Enforcement for Criminal Alien Removal Act 2003 (the United States of America, 2003).

38 Amin Asfari and Anas Askar, 'Understanding Muslim Assimilation in America: An Exploratory Assessment of First \& Second-Generation Muslims Using Segmented Assimilation Theory', Journal of Muslim Minority Affairs, $\quad 40.2 \quad$ (2020), <https://doi.org/10.1080/13602004.2020.1781467>. 
“...No State shall make or enforce any law which shall abridge the privileges or immunities of citizens of the United States; nor shall any State deprive any person of life, liberty, or property, without due process of law; nor deny to any person within its jurisdiction the equal protection of the laws." 39

Muslim life in the US seems to be affected by the political configuration of the government. During Trump's presidency, there are many negative statements and perceptions of Islam during his 2016 presidential campaign. That was revealed from an interview with $\mathrm{CNN}$ "Islam hates us" ${ }^{40}$ Perhaps surprisingly, the surveys show that Americans generally have worse sentiment towards Islam rather than religious groups as well as racial, sexual, and political groups. Furthermore, reports of racist treatment among Muslims are considered normal cases and have increased over time. ${ }^{41}$

Donald Trump, in January 2017, announced refugee entry bans and temporary travel bans from seven Muslim-majority countries. ${ }^{42}$ US Muslims perceived that US society did not see Islam as a part of the mainstream US community. ${ }^{43}$ There are some controversial policies during Trump's presidency related to human rights issues, namely:

\section{Muslim and visa entry ban policy to the US}

After 6 days as a president, Donald Trump made a controversial policy, by banning entry of

39 Amendment 14-Citizenship Rights. Retified 7/9/1868. The Constitution of the United States.

40 Jenna Johnson and Abigail Hauslohner, "I Think Islam Hates Us': A Timeline of Trump's Comments about Islam and Muslims," 2017 $<$ https://www.washingtonpost.com/news/postpolitics/wp/2017/05/20/i-think-islam-hates-us-atimeline-of-trumps-comments-about-islam-andmuslims/> [accessed 15 December 2021].

${ }^{41}$ Daniel Herda, 'Reactive Ethnicity and Anticipated Discrimination among American Muslims in Southeastern Michigan', Journal of Muslim Minority Affairs, 38.3 (2018), 372-391

<https://doi.org/10.1080/13602004.2018.1524136>.

42 Saltanat Liebert, Mona H. Siddiqui, and Carolin Goerzig, 'Integration of Muslim Immigrants in Europe and North America: A Transatlantic Comparison', Journal of Muslim Minority Affairs, 40.2 (2020), 196-216 <https://doi.org/10.1080/13602004.2020.1777663>. people from certain Muslim-majority countries to the US. ${ }^{4}$ Trump approved 10 executive instructions signed on January 20, 2017, including his last campaign to ban visas for several Muslim countries such as Iraq, Iran, Syria, Libya, Yemen, Sudan, and Somalia, and are valid for 30 working days. In addition, Trump banned the entry of refugees for several months, except that fleeing persecution against religious minorities. ${ }^{45}$ While not for all Muslim countries, analysis of the Trump administration's travel ban shows fewer legal immigrants and temporary visa holders came to America in 2018 than the 5 Muslim-majority countries targeted by the ban. In fact, the Supreme Court upheld Trump's policy on the grounds that it was a matter of national security. According to policy observers, this order reflects anti-Muslim prejudice by including North Korea and Venezuela as excuses. ${ }^{46}$

\section{US Muslim citizens registration}

Trump, as in his campaign, promised to reregister US Muslims residency, but this was assumed discriminatory not only by US Muslim but also by other community groups and other religions. This policy raised Islamophobia and had a significant impact on many people, especially Muslim citizens. The Muslim issue is considered the most popular object for political elites in the US. ${ }^{47}$ The immigration registration policy was implemented in the Bush era. However, this policy experienced many obstacles until it emerged from

43 "U.S. Muslims Concerned About Their Place in Society, but Continue to Believe in the American Dream: Findings from Pew Research Center's 2017 Survey of U.S. Muslims," Pew Research Center, 2017 <https://www.pewforum.org/2017/07/26/findingsfrom-pew-research-centers-2017-survey-of-us-muslims/> [accessed 17 April 2021].

44 Ibnu Zulian, 'Analisis Pengaruh Islomophobia Terhadap Kebijakan Luar Negeri Amerika Serikat di Pemerintahan Donald Trump', Jurnal PIR Vol.3 No. 2 Februari 2019, 3.2 (2019), 150-151

${ }^{45}$ Zulian.

46 Stuart Anderson, "Muslim Travel Ban: Less Immigration And Few Waivers," 2019 <https://www.forbes.com/sites/stuartanderson/2019/03 $/ 11 /$ muslim-travel-ban-less-immigration-and-fewwaivers/?sh $=244 \mathrm{e} 7 \mathrm{~b} 6727 \mathrm{f0}>\quad$ accessed 15 December 2021].

$$
\text { 47Zulian., p. } 152
$$


many parties. Even in the Obama era, this policy was suspended even though it has not been completely abolished. Donald Trump is campaigning to re-establish a database of all immigrants entering the United States. This database will probably be similar to the National Security Entry-Exit Registration System (NSEERS) that Bush issued after the terrorist attacks of September 11, 2001. This policy has disproportionately targeted Arabs and Muslims as a point of contention between rights groups. ${ }^{48}$

\section{False bumanitarian in the safe zone}

Trump's proposed policy is to facilitate the establishment of safe zones for refugees in Syria and the Middle East, in an effort to avoid accusations of discriminatory immigration policies. Indeed, Trump has said that establishing safe zones is an inseparable part of efforts to preserve humanity in the Middle East. Trump's claim is a political statement aimed at giving a friendly image towards refugees. In addition, he stated that religious freedom is the foundation of American society through his statement that the right of the believer to freely practice their beliefs is one of the shared values of Americans. ${ }^{49}$

The discriminatory policies issued by Trump often receive international attention, considering that America is a country that upholds religious freedom as part of human rights. ${ }^{50}$ This raises the notion that the US is a country that often

${ }^{48}$ Nadeem Muaddi, “The Bush-Era Muslim Registry Failed. Yet the US Could Be Trying It Again," CNN Politics, 2016

<https://edition.cnn.com/2016/11/18/politics/nseersmuslim-database-qa-trnd/index.html $>$ [accessed 15 December 2021].

49 Prashant Waikar, 'Reading Islamophobia in Hegemonic Neoliberalism through a Discourse Analysis of Donald Trump's Narratives', Journal of Muslim Minority Affairs, $\quad 38.2 \quad$ (2018), $153-178$ < https://doi.org/10.1080/13602004.2018.1466490>.

${ }^{50}$ Ramdan Febrian, "Larangan Masuk Warga Negara Muslim di AS: Digagas Obama, Dimanfaatkan Trump, Dicabut Biden," Voice of Indonesia, 2020 <https:/ /voi.id/bernas/19520/larangan-masuk-warganegara-muslim-di-as-digagas-obama-dimanfaatkan-trumpdicabut-biden $>$ [accessed 19 April 2021].

51 Christiyaningsih, "Biden Ends Travel Ban for

Muslim Countries,” Republika.co.id, 2021 <https://www.republika.co.id/berita/qna0ib528247552/b contradicts the principles of its constitution and international law. ${ }^{51}$ Trump's policy of banning Muslim travel was sued in federal and district courts and overturned, arguing that a policy of prohibiting discrimination against Muslims would violate the Establishment Clause of the First Amendment. ${ }^{52}$ At last, the Supreme Court decided to allow some of Trump's Muslim ban policies after using the Lemon test. ${ }^{53}$

In 2019, Trump government officials began to pay attention to international religious freedom. While speaking at the UN Event on Religious Freedom, Trump said that "as a President, protecting religious freedom is one of my highest priorities, and America will always be a voice for religious persecution victims everywhere." Trump's rhetoric about religious freedom seems to be a political stance and a diversion from his bad image in the eyes of the world (Islam). His orientalist view assumed that Muslims are a group that should not be part of US society. Anti-Muslim discourse continually appeared despite the fact that $10 \%$ of the violence cases were committed by white supremacist or anti-Muslim groups, as was the case with several terror incidents in the US in 2017.54

Finally, good news came after Biden took over Trump's presidency. One of his campaigns was regarding Muslim travel ban which was finally realized in the early days of his government. Based on Biden's proclamation, the discriminatory ban

iden-akhiri-larangan-perjalanan-bagi-negara-muslim > [accessed April 18, 2021].

52 History.com Editors, "Freedom of Religion," History.com, 2018

<https://www.history.com/topics/united-statesconstitution/freedom-of-religion $>$ [accessed 19 April 2021].

53 The Council on American-Islamic Relations recorded 2,599 hate crimes against American Muslims in 2017, representing a 94 percent jump from 2014, which rights and advocacy groups attribute to Donald Trump's "Muslim ban" and his discourses and policies that encourage Islamophobia. See, Purnama Ayu Rizky, "Revocation of Biden's 'Muslim Prohibition', a Sign of Peace With Iran? -iran-analysis/> [accessed April 19, 2021]. 54 Ali Jalalian Daghigh and Hajar Abdul Rahim, 'Representation of Muslim Minorities in Politicians' Discourse: Jacinda Ardern vs. Donald Trump', Journal of Muslim Minority Affairs, 40.2 (2020), 179-195 <https://doi.org/10.1080/13602004.2020.1773099>. 
was suspended. ${ }^{55}$ This is an effort to strengthen and protect the entire world community. Executive Instruction 13780 of March 6, 2017, declared that the proclamations 9645, 9723, and 9983 are officially revoked and are no longer valid..$^{56}$

Biden is assumed capable to carry on religious freedom changes, especially for Muslims in America. Since the beginning of his presidential candidate's campaign, he has been quite aggressive in conveying freedom for Muslims. Moreover, in his early presidency, he revoked Donald Trump's previous Muslim ban. Some of Biden's warm manner is embracing all religious groups in the US such as conveying the Ramadhan greetings to all Muslims in America and around the world through his Instagram accounts. He texted "As the crescent moon ushers in the month, Jill and I send our warmest greetings and best wishes to Muslim communities in the United States and around the world. Ramadan Kareem." 57

Furthermore, cited from VOA Indonesia, Biden expressed that Muslim citizens in the US have given color to the country since its first establishment. Muslims played many roles in handling the Covid-19 virus, such as being health workers or public servants in several sectors. He added that Islam has played an important role in the ongoing fight for racial equality and social justice. However, it appears that Muslim Americans are still the targets of bullying, bigotry, and hate crimes. This discrimination and attacks are unacceptable and must be stopped. No one in America should live in fear of professing his faith. Thus, the government works tirelessly to protect the rights and security of all citizens. Biden also

55 Al Jazeera and News Agencies, 'US 'Muslim Ban' Set to End 'on Day One' of Biden Presidency," US Elections 2020, 2020

<https://www.aljazeera.com/news/2020/11/8/usmuslim-ban-set-to-end-on-day-one-of-biden-presidency $>$ [accessed 15 December 2021].

56 Shareamerica Editors, "Biden Akhiri Larangan Imigrasi Diskriminatif," Share.America.Gov, 2021 $<$ https:// share.america.gov/id/biden-akhiri-laranganimigrasi-diskriminatif/ $>$ [accessed 17 April 2021]. quotes a Quran verse in Surah An Nur: 35 that "Allah is Light of the heaven and the earth". 58

\section{US Muslim Participation in the Political and Public Sphere}

Muslim life in the US is not only about religious sentiments. Freedom of speech and participation in public spaces is wide open for Muslims. The freedom of American citizens to hold positions in state institutions has been guaranteed by the state constitution as enshrined in the United States Constitution in Article 6 concerning Debt, Supremacy and Oaths:

"The Senators and Representatives before mentioned, and the Members of the several State Legislatures, and all executive and judicial Officers, both of the United States and of the several States, shall be bound by Oath or Affirmation, to support this Constitution; but no religious Test shall ever be required as a Qualification to any Office or public Trust under the United States."

The article explicitly states that the opportunities of a public official in the regardless of religion. In other words, everyone who meets the legal qualifications and state laws has the right to be sworn in and serve as public officials, both in the legislative, executive, and judicial institutions.

According to Nihad Awad, executive director of the CAIR, the past four years of Trump's presidency have been a time of fighting for justice and civil rights defense for American Muslims. This is a kind of Muslim self-defense against discrimination from the White House. On the other side, Trump's presidency has motivated many people to get involved in politics, advocacy. Awad saw the enthusiasm of US Muslims not only

\footnotetext{
57 Potus, "A Post of Ramadan Kareem," Instagram Official Account of President Joe Biden, 2021. [accessed 16 December 2021].

58 Voaindonesia Editors, "Sampaikan Pesan Ramadan, Biden Kutip Surat An Nur," VOAIndonesia, 2021 $<$ https://www.voaindonesia.com/a/sampaikan-pesanramadan-biden-kutip-surat-an-nur/5850859.html> [accessed 18 April 2021].

59 Article VI. Debts, Supremacy and Oaths, The Constitution of the United States.
} 
in voting but also in participating in strategic positions in government aimed to promote peace and justice for all US citizens. A survey reported that nearly $40 \%-50 \%$ of the approximately $300 \mathrm{US}$ Muslims who participated in the general election succeeded in holding political office at the federal, state, or local levels. ${ }^{60}$

Some American Muslims of United States Congress are as follows: Some of the American Muslim public officials who occupy the strategic seats are as follows: Sadaf Jaffer, the first US Muslim woman of Pakistani descent to become Mayor in Montgomery, New Jersey, in 2019. ${ }^{61}$ Ilhan Omar, a US Muslim woman of Somali descent, became the first Muslim woman served as a member of the US Congress. ${ }^{62}$ Rashida Tlaib, a Muslim woman who successfully served as a member of the US Congress from the Democrats. ${ }^{63}$ Nadia Mohamed, a young Muslim woman served on the St. Louis Park Minnesota. ${ }^{64}$ Saud Anwar, mayor of South Windsor for two terms, 2013-2015 and 2017-2019. Currently, he is

${ }^{60}$ Nashih Nashrullah, "Beginilah Sosok Trump dan Amerika Serikat Menurut Umat Islam," Msn.Com, 2020 $<$ https://www.msn.com/id-id/berita/nasional/beginilahsosok-trump-dan-amerika-serikat-menurut-umat-islam/arBB1ayWZA> [accessed 19 April 2021].

${ }^{61}$ Utami Hussin, "Sadaf Jaffer, Muslimah Pertama Yang Menjabat Walikota di Amerika," VOA Indonesia, 2019 $<$ https://www.voaindonesia.com/a/sadaf-jaffermuslimah-pertama-yang-menjabat-walikota-di-amerika/4874262.html> [accessed 16 June 2021].

${ }^{62}$ Syarifudin, "Selain Baycora, Ini 10 Pejabat Muslim di Amerika Serikat," Sinconews.Com, 2020 <https://daerah.sindonews.com/artikel/jabar/17629/sela in-baycora-ini-10-pejabat-muslim-di-amerikaserikat? showpage $=$ all $>$ [accessed 20 April 2021].

${ }^{63}$ Eli Watkins and Sunlen Serfaty, "Rashida Tlaib Becomes First Muslim Woman to Preside over House Floor," CNN, 2019

$<$ https://edition.cnn.com/2019/05/15/politics/firstmuslim-woman-preside-house-floor/index.html> [accessed 16 June 2021].

${ }^{64}$ Syarifudin, "Selain Baycora, Ini 10 Pejabat Muslim Di Amerika Serikat,”... [accessed 20 April 2021].

65 Joe O'Leary, "Saud Anwar Sworn in as State Senator," Senatedems.Ct.Gov, 2019 <http://www.senatedems.ct.gov/anwar-news/2249 anwar-190301\#sthash.KIwiBeOz.dpbs> [accessed 16 June 2021].

${ }^{66}$ Andrian Saputra, "Politisi Muslim Akan Penuhi Wajah Perpolitikan Amerika?," Republika.Co.Id, 2019 <https://khazanah.republika.co.id/berita/q0nc1t320/poli a Democratic State Senator. ${ }^{65}$ Sagita Khalid, a young 23-year-old politician who serves on the Lewiston City Council. ${ }^{66}$ Keith Ellison, the first Muslim to be elected to the US Congress. ${ }^{67}$ Andre Carson, second Muslim served in the US Congress 7th District of Indiana. ${ }^{68}$ Abid Riaz Qureshi, a federal judge for the District of Columbia nominated by President Obama in 2016. ${ }^{69}$ Ghazala Hashmi, the first Muslim Democrat to become a state Senator in Virginia. ${ }^{70}$ Another new history recorded Ibrahim Mike Baycora, a Muslim man of US-Turkish descent who was appointed to become the 17th Police Chief in Paterson City, New Jersey in $2020 .^{71}$

The constitutional guarantees of the freedom and participation of American Muslims in the public sphere seem quite convincing as stated in the US Consitution that "...no religious Test shall ever be required as a Qualification to any Office or public Trust under the United States". ${ }^{72}$ These allow American Muslims to voice their human rights. In addition, this participation can be

tisi-muslim-akan-penuhi-wajah-perpolitikan-amerika> [accessed 16 June 2021].

67 Nikki Schwab, "Rep. Keith Ellison: Being a Muslim in Congress Has Gotten Better," Usnews.Com, 2014 $<$ https://www.usnews.com/news/blogs/washingtonwhispers/2014/02/10/rep-keith-ellison-being-a-muslimin-congress-has-gotten-better $>$ [accessed 16 June 2021].

68 Laura Hibbard, "André Carson, Indiana Congressman, Says U.S. Public Schools Should Be Modeled After Islamic Schools," Huffpost.Com, 2012 $<$ https://www.huffpost.com/entry/andre-carson-schoolsshould-be-modeled-after-madrassa_n_1654510> [accessed 16 June 2021].

${ }^{69}$ Chris Fuchs, "Obama Nominates Possible First Muslim-American Judge to Federal Court," Nbcnews, 2016 $<$ https://www.nbcnews.com/news/asianamerica/obama-nominates-possible-first-muslimamerican-judge-federal-court-n643831> [accessed 16 June 2021].

${ }^{70}$ Sean Galvin, "Who Is Ghazala Hashmi, Virginia's First Muslim State?," Vadogwood.Com, 2019 $<$ https://vadogwood.com/2019/11/12/who-is-ghazalahashmi-virginias-first-muslim-state-senator/ $>$ [accessed 16 June 2021

71 Victor Maulana, "Ibrahim Baycora, Muslim Pertama Jabat Kepala Polisi di Amerika Serikat," Sindonews.Com

$<$ https://daerah.sindonews.com/artikel/jabar/17437/ibra him-baycora-muslim-pertama-jabat-kepala-polisi-diamerika-serikat,> [accessed 16 June 2021].

72 Article VI. Debts, Supremacy and Oaths, The Constitution of the United States. 
an effort to improve the image of Muslims in the eyes of the world. Although government spokesmen have discussed many issues facing Muslims, such as racial, religious and other forms of prejudice, the government still has many things to do. The Human Rights Commission recommends developing an environment that implements restorative justice to help resolve hate crimes in a complete manner.

The End Racial Profiling Act 2004 contains a clause to revise training tactics aimed at eliminating racially motivated action. ${ }^{73}$ The Speaker of the US House of Representatives, Nancy Pelosi, expressed that the Late Racial Profile Act of 2004 prohibits racial abuse at all levels of law enforcement, federal, state, and local. ${ }^{74}$ Several Muslims organizations are actively raising awareness about Islam among governments, law enforcement agencies, and educational institutions. However, there is still much work to be done by the agency to bridge the gap between Muslims and non-Muslims. In addition, Muslims should strive to learn about the Bill of Rights, the Constitution, and the act amending immigration laws. Both of these initiatives are expected to help Muslims to better mingle with the community, actively participate in their activities, and also increase their knowledge about the country they live in. ${ }^{75}$

\section{Conclusion}

The existence of Muslim life in the United States tends to follow the government's political configuration. This can be seen from various state policies that show discriminatory discourses and rejection of Muslims. In fact, the constitution explicitly states that freedom of religion is a human right guaranteed by the constitution. So, the state must protect every Muslim to live in peace and free from various discriminatory actions and policies.

73 The End Racial Profiling Act 2004 (the United States of America, 2004).

${ }^{74}$ Aisha Peña, 'Protecting Muslim Civil and Human Rights in America: The Role of Islamic, National, and International Organizations', Journal of Muslim Minority Affairs, $\quad 27.3 \quad$ (2007), 387-400 <https://doi.org/10.1080/13602000701737236>.
Nevertheless, it seems that the US is starting to realize the important role of Muslims in nationbuilding efforts. It is marked by the large number of Muslim politicians who participate and occupy strategic positions in the country. Some discriminatory policies appear to be abolished and directed towards humanist policies, as was done at the beginning of the Joe Biden presidency. $\mathrm{He}$ revoked policies that were unconstitutional and violated human rights, especially those related to Islamic sentiment. The United States always strives to uphold the constitution and human rights in providing security and peace for Muslims and adherents of other religions.

\section{Acknowledgements}

The author would like to thank the Ministry of Religious Affairs Indonesia and Graduate School of State Islamic University of Syarif Hidayatullah Jakarta

\section{References}

\section{Books}

Corcoran, Ann, Refugee Resettlement and The Hijra to America (United States of America: Security Policy Press, 2015)

Fairclough, Norman, and Isabela Fairclough, Political Discourse Analysis: A Method for Advanced Students. (United Kingdom: Routledge, 2012)

Loveland, Ian, Constitutional Law, Administrative Law, and Human Rights: A Critical Introduction, 6th Editio (Great Britain: Oxford University Press, 2012)

Pennings, Paul, Hans Keman, and Jan Kleinnijenhuis, Doing Research in Political Science (London: Sage Publications, 2006)

\section{Journals}

Asfari, Amin, and Anas Askar, "Understanding Muslim Assimilation in America: An

75 75Aisha Peña, 'Protecting Muslim Civil and Human Rights in America: The Role of Islamic, National, and International Organizations', Journal of Muslim Minority Affairs, $\quad 27.3 \quad$ (2007), $\quad 387-400$ <https://doi.org/10.1080/13602000701737236>. 
Exploratory Assessment of First \& SecondGeneration Muslims Using Segmented Assimilation Theory," Journal of Muslim Minority Affairs, 40.2 (2020), 217-34 $<$ https://doi.org/10.1080/13602004.2020. 1781467>

Bacquet, Sylvie, "Religious Freedom in a Secular Society: An Analysis of the French Approach to Manifestation of Beliefs in the Public Sphere," SSRN Electronic Journal, 9.October (2012), 1-15 <https://doi.org/10.2139/ssrn.1753229>

Bakar, Abu, "Konsep Toleransi Dan Kebebasan Beragama," Toleransi: Media Komunikasi Umat Beragama, 7.2 (2015), 123-31

Ernada, Sus Eko, "Issues of Compatibility of Human Rights and Islam: The Experience of Egypt and Indonesia," Journal of Indonesian Islam, $1.1 \quad$ (2007), 100-134 $<$ https://doi.org/10.15642/JIIS.2007.1.1.1 00-134>

Fuad, Ahmad Nur, A. Arbaiyah, Syafiq Mughni, and Achmad Jainuri, "Islam and Human Rights in Indonesia: An Account of Muslim Intellectuals' Views," Al-Jami'ab: Journal of Islamic Studies, 45.2 (2007), 241-87 $<$ https://doi.org/10.14421/ajis.2007.452.2 41-287>

Herda, Daniel, "Reactive Ethnicity and Anticipated Discrimination among American Muslims in Southeastern Michigan," Journal of Muslim Minority Affairs, $38.3 \quad$ (2018), 372-91 $<$ https://doi.org/10.1080/13602004.2018. $1524136>$

Hossain, Kazi I., "Understanding Islam in the U.S. Classroom: A Guide for Elementary School Teachers," Multicultural Education, 20.2 (2013), 49-52

Jalalian Daghigh, Ali, and Hajar Abdul Rahim, "Representation of Muslim Minorities in Politicians' Discourse: Jacinda Ardern vs. Donald Trump," Journal of Muslim Minority Affairs, $\quad 40.2 \quad$ (2020), 179-95 $<$ https://doi.org/10.1080/13602004.2020. $1773099>$

Kahera, Akel Ismail, "Urban Enclaves, Muslim Identity and the Urban Mosque in America," Journal of Muslim Minority Affairs, 22.2 (2002),
$369-80$

$<$ https://doi.org/10.1080/1360200022000 027320>

Karibi, Rhoda Asikia Ige Nee, "Religion, Human Rights and the Challenges of Freedom," Peuradeun, 3.1 (2015), 39-54

Kartini, Indriana, "Dinamika Minoritas Muslim Di Amerika Serikat," Jurnal Penelitian Politik, $2.1 \quad$ (2005), 97-107 <https://doi.org/10.14203/jpp.v2i1.405>

Liebert, Saltanat, Mona H. Siddiqui, and Carolin Goerzig, "Integration of Muslim Immigrants in Europe and North America: A Transatlantic Comparison," Journal of Muslim Minority Affairs, 40.2 (2020), 196-216 $<$ https://doi.org/10.1080/13602004.2020. $1777663>$

Malaka, Zuman, "Ham dan Demokrasi dalam Dunia Islam," Al-Qanun, 12.2 (2009) $<$ https://doi.org/https://doi.org/10.15642 /alqanun.2009.12.2.359-384>

Mark, R. Shulman, "The Four Freedoms: Good Neighbors Make Good Law and Good Policy in a Time of Insecurity," Fordham Law Review, $\quad 77.2 \quad$ (2008), 555-81 $<$ https://ssrn.com/abstract $=1287160>$

Milia, Jana, and Yusnarida Eka Nizmi, "Kebijakan Luar Negeri Amerika Serikat Terhadap Kelompok Terorisme Al-Qaeda Pada Masa Pemerintahan Barack Obama," JOM FISIP, 2.2 (2015)

Muhtarom, Ahmad, "Diskursus Islam dan Hak Asasi Manusia (Kajian Universalitas dan Kasus Pelanggaran Hak Asasi Manusia)," FIKRI: Jurnal Kajian Agama, Sosial Dan Budaya, $\quad 2.1 \quad$ (2017), 113 <https://doi.org/10.25217/jf.v2i1.83>

Peña, Aisha, "Protecting Muslim Civil and Human Rights in America: The Role of Islamic, National, and International Organizations," Journal of Muslim Minority Affairs, $\quad 27.3 \quad$ (2007), $\quad 387-400$ $<$ https://doi.org/10.1080/1360200070173 $7236>$

Purwanto Joko, Adi, "Sekuritisasi Terhadap Imigran Negara Mayoritas Muslim Di Amerika Serikat Era Presiden Donald Trump," Spektrum, 18.1 (2021) 
Ropi, Ismatu, "Konstitusi dan Nomenklatur Kebebasan Beragama: Pengalaman Berbagai Negara," Jurnal Ilmu Ushuluddin, 7.1 (2020), 57-82

$<$ https://doi.org/10.15408/iu.v7i1.14411>

Saputri, Oktoviana Banda, "Diskriminasi Ras dan Hak Asasi Manusia di Amerika Serikat: Studi Kasus Pembunuhan George Floyd," Jurnal Sosiologi Pendidikan Humanis, 5.2 (2020), 120 <https://doi.org/10.17977/um021v5i2p12 $0-133>$

Takdir, Mohammad, "Contestation and the Roles of Islam in The Public Sphere: A Sociological Analysis of Religious Secularization in Indonesia and the West," Afkaruna: Indonesian Interdisciplinary Journal of Islamic Studies, $20.2 \quad$ (2020) $<$ https://doi.org/10.18196/aiijis.2020.0119 .154-174>

Thontowi, Jawahir, "Kebijakan Presiden Trump dan Respon Masyarakatnya Terhadap Larangan Muslim Arab Tinggal di Amerika Serikat," Jurnal Hukum IUS QULA IUSTUM, $24.3 \quad$ (2017), 369-92 $<$ https://doi.org/10.20885/iustum.vol24.is s3.art2>

Tiolina, Jessica, "Analisis Serangan Drone dalam Aksi Counter Terrorism Terhadap Hubungan Amerika Serikat dan Pakistan Pada Masa Pemerintahan Presiden Barack Obama," Journal of International Relations, 4.4 (2018), 858-67 <http://ejournals1.undip.ac.id/index.php/jihi>

Utomo, Adhika Isthianto, "Kepentingan Amerika Serikat dan Prancis dalam Intervensi Kemanusiaan di Libya Pada Tahun 2011," Journal of International Relations, 4.4 (2018), 822-31

$<$ https://ejournal3.undip.ac.id/index.php/j ihi/article/view/22004>

Waikar, Prashant, "Reading Islamophobia in Hegemonic Neoliberalism through a Discourse Analysis of Donald Trump's Narratives," Journal of Muslim Minority Affairs, $38.2 \quad$ (2018), 153-78 $<$ https://doi.org/10.1080/13602004.2018. $1466490>$

Zulian, Ibnu, "Analisis Pengaruh Islomophobia Terhadap Kebijakan Luar Negeri Amerika Serikat di Pemerintahan Donald Trump,"
Jurnal PIR Vol.3 No. 2 Februari 2019, 3.2 (2019), 140-55

\section{Online Database}

"Religion and Constitution," Legal Information Institute

$<$ https://www.law.cornell.edu/wex/religio n_and_the_constitution $>$ [accessed 19 April 2021]

"U.S. Muslims Concerned About Their Place in Society, but Continue to Believe in the American Dream: Findings from Pew Research Center's 2017 Survey of U.S. Muslims," Pew Research Center, 2017 $<$ https://www.pewforum.org/2017/07/26 / findings-from-pew-research-centers-2017survey-of-us-muslims/> [accessed 17 April 2021]

Agencies, Al Jazeera and News, 'US 'Muslim Ban' Set to End 'on Day One' of Biden Presidency," US Elections 2020, 2020 <https://www.aljazeera.com/news/2020/ 11/8/us-muslim-ban-set-to-end-on-dayone-of-biden-presidency $>$ [accessed 15 December 2021]

Anderson, Stuart, "Muslim Travel Ban: Less Immigration And Few Waivers," 2019 $<$ https://www.forbes.com/sites/stuartand erson/2019/03/11/muslim-travel-ban-lessimmigration-and-few-

waivers/?sh $=244 \mathrm{e} 7 \mathrm{~b} 6727 \mathrm{f} 0>$ [accessed 15 December 2021]

Editors, History.com, "Freedom of Religion," History.Com, 2018 $<$ https://www.history.com/topics/unitedstates-constitution/freedom-of-religion> [accessed 19 April 2021]

Editors, Shareamerica, "Biden Akhiri Larangan Imigrasi Diskriminatif," Share.America.Gov, $2021<$ https://share.america.gov/id/bidenakhiri-larangan-imigrasi-diskriminatif/> [accessed 17 April 2021]

Editors, Voaindonesia, "Sampaikan Pesan Ramadan, Biden Kutip Surat An Nur," VOAIndonesia, 2021 $<$ https://www.voaindonesia.com/a/sampa ikan-pesan-ramadan-biden-kutip-surat-annur/5850859.html $>$ [accessed 18 April 2021]

Febrian, Ramdan, "Larangan Masuk Warga 
Negara Muslim di AS: Digagas Obama, Dimanfaatkan Trump, Dicabut Biden," Voice of Indonesia, 2020 $<$ https://voi.id/bernas/19520/laranganmasuk-warga-negara-muslim-di-as-digagasobama-dimanfaatkan-trump-dicabutbiden $>$ [accessed 19 April 2021]

Fuchs, Chris, "Obama Nominates Possible First Muslim-American Judge to Federal Court," Nbonews, 2016 $<$ https://www.nbcnews.com/news/asianamerica/obama-nominates-possible-firstmuslim-american-judge-federal-courtn643831> [accessed 16 June 2021]

Hibbard, Laura, "André Carson, Indiana Congressman, Says U.S. Public Schools Should Be Modeled After Islamic Schools," Huffpost.Com, 2012 $<$ https://www.huffpost.com/entry/andrecarson-schools-should-be-modeled-aftermadrassa_n_1654510> [accessed 16 June 2021]

Hussin, Utami, "Sadaf Jaffer, Muslimah Pertama Yang Menjabat Walikota di Amerika," VOA Indonesia, 2019 $<$ https://www.voaindonesia.com/a/sadafjaffer-muslimah-pertama-yang-menjabatwalikota-di-amerika-/4874262.html> [accessed 16 June 2021]

Johnson, Jenna, and Abigail Hauslohner, "I Think Islam Hates Us': A Timeline of Trump's Comments about Islam and Muslims," 2017 $<$ https://www.washingtonpost.com/news /post-politics/wp/2017/05/20/i-thinkislam-hates-us-a-timeline-of-trumpscomments-about-islam-and-muslims/> [accessed 15 December 2021]

Lipka, Michael, "Muslims and Islam: Key Findings in the U.S. and around the World," Pew Research Center, 2017 $<$ https://www.pewresearch.org/facttank/2017/08/09/muslims-and-islam-keyfindings-in-the-u-s-and-around-theworld/> [accessed 18 April 2021]

Maulana, Victor, "Ibrahim Baycora, Muslim Pertama Jabat Kepala Polisi di Amerika Serikat," Sindonews.Com, 2020 $<$ https://daerah.sindonews.com/artikel/ja bar/17437/ibrahim-baycora-muslimpertama-jabat-kepala-polisi-di-amerika- serikat,> [accessed 16 June 2021]

Mohamed, Besheer, "Muslims Are a Growing Presence in U.S., but Still Face Negative Views from the Public," Pew Research Center (the United States of America, 2021) $<$ https://www.pewresearch.org/facttank/2021/09/01/muslims-are-a-growingpresence-in-u-s-but-still-face-negativeviews-from-the-public/> [accessed

December 2021]

Muaddi, Nadeem, "The Bush-Era Muslim Registry Failed. Yet the US Could Be Trying It Again," CNN Politics, 2016 $<$ https://edition.cnn.com/2016/11/18/po litics/nseers-muslim-database-qatrnd/index.html> [accessed 15 December 2021]

Nashrullah, Nashih, "Beginilah Sosok Trump dan Amerika Serikat Menurut Umat Islam," Msn.Com, $2020<$ https://www.msn.com/idid/berita/nasional/beginilah-sosok-trumpdan-amerika-serikat-menurut-umatislam/ar-BB1ayWZA> [accessed 19 April 2021]

O'Leary, Joe, "Saud Anwar Sworn in as State Senator," Senatedems.Ct.Gov, 2019 $<$ http://www.senatedems.ct.gov/anwarnews/2249-anwar190301\#sthash.KIwiBeOz.dpbs> [accessed 16 June 2021]

Saputra, Andrian, "Politisi Muslim Akan Penuhi Wajah Perpolitikan Amerika?," Republika.Co.Id, 2019 $<$ https://khazanah.republika.co.id/berita/ q0nc1t320/politisi-muslim-akan-penuhiwajah-perpolitikan-amerika> [accessed 16 June 2021]

Schwab, Nikki, "Rep. Keith Ellison: Being a Muslim in Congress Has Gotten Better," Usnews. Com, 2014 $<$ https://www.usnews.com/news/blogs/w ashington-whispers/2014/02/10/rep-keithellison-being-a-muslim-in-congress-hasgotten-better $>$ [accessed 16 June 2021]

Syarifudin, "Selain Baycora, Ini 10 Pejabat Muslim di Amerika Serikat," Sinconews.Com, 2020

$<$ https://daerah.sindonews.com/artikel/ja bar/17629/selain-baycora-ini-10-pejabatmuslim-di-amerika-serikat?showpage $=$ all $>$ 
[accessed 20 April 2021]

Watkins, Eli, and Sunlen Serfaty, "Rashida Tlaib Becomes First Muslim Woman to Preside over House Floor," CNN, 2019 $<$ https://edition.cnn.com/2019/05/15/po litics / first-muslim-woman-preside-housefloor/index.html $>$ [accessed 16 June 2021]

\section{Digital and Social Media}

Potus, "A Post of Ramadan Kareem," Instagram Official Account of President Joe Biden, 2021. [accessed 19 December 2021]

\section{Statutes}

Declaration of Independence (the United States of America, 1776)
The Clear Law Enforcement for Criminal Alien Removal Act 2003 (the United States of America, 2003)

The Constitution of the United States (United States)

The End Racial Profiling Act 2004 (the United States of America, 2004)

\section{Report and Working Paper}

Bagby, Ihsa, The American Mosque 2020: Growing and Evolving, Report 1 of the US Mosque Survey 2020: Basic Characteristics of the American Mosque (the United States of America, 2020)

Human Rights, Terrorism and Counter-Terrorism (Switzerland, 2008)

Marks, Stephen P, Human Rights: A Brief Introduction, Harvard School of Public Health, 2014 